«Без лица в личине»: о жанре загадки на уроках русского языка как иностранного

Аннотация: В статье рассматриваются методические аспекты изучения фольклорного текста в иностранной аудитории. В частности, речь идет о приемах и методах анализа жанра загадки на занятиях по РКИ. Описываются функции загадок, принципы их отбора и типы заданий на уроках РКИ. Доказывается, что загадки обладают значительным лингвометодическим потенциалом.

Ключевые слова: лингвометодический потенциал, русский как иностранный, загадка

Mu Yuxi (Tomsk, Russia)

\title{
"There is no Face in the Mask": The Riddle in the Lecture of Russian for Foreigners
}

Abstract: The article focuses on the teaching methodology of folklore in lectures for foreigners. Particularly, the article is about reception and methods for analyzing the genre of the riddle in Russian as a foreign language in classes. It also studies the functions of the riddle by analyzing principles and types in the lecture to prove the riddle's potential for foreign Russian students.

Key words: linguistic teaching potential, Russian as a foreign language, riddle

В последнее время в преподавании иностранного языка большое внимание уделяется его связи с культурологическом компонентом как основой овладения другой языковой картиной мира. Неотъемлемой частью культуры любого народа является фольклор, «устное словесное и музыкальное народное творчество» [Адоньева 2004: 5]. Преподавание и изучение иностранного языка (в том числе РКИ) без привлечения текстов устного народного творчества обедняет процесс постижения этого языка, создает лакуны культурно-языкового характера. По замечанию ученых, «культуроносными не только в плане лексики, но и в плане содержания являются в первую очередь фольклорные тексты, поэтому их включение в программу обучения РКИ вполне оправданно» [Белозубова, Титова 2010: 184].

Одним из фольклорных жанров, используемых на занятиях по РКИ, является жанр загадки. «Загадки - яркий образец фольклора с игровыми художественными функциями. ...в загадках отражены представления и понятия обо всем том, что 
окружает человека в быту» [Аникин 2001: 496]. Короткие тексты загадок отражают богатый опыт и ментальность народа, их содержание связано с культурой, историей, географией, природой и т. д. Загадки формируют навыки логического мышления, развивают наблюдательность, поэтому они используются как одно из первых средств обучения в семейном и дошкольном образовании.

\section{ФУНКЦИИ ЗАГАДОК В ОБУЧЕНИИ}

Жанр загадки в процессе обучения имеет следующие функции:

1) развлекательную: делает урок, занятие интереснее, дает возможность переключить внимание учащихся и отдохнуть;

2) познавательную: позволяет выявить признаки явлений и предметов с точки зрения носителей культуры;

3) развивающую: загадки развивают логическое мышление, способствуют формированию у человека образного мышления, способности видеть мир в образах;

4) эстетическую: учит понимать красоту родного и изучаемого языка, воспринимать богатство культуры.

Кроме того, на занятиях по РКИ с помощью жанра загадки учащиеся могут приобрести ряд навыков.

1) Актуализировать значения слов. Для отгадывания загадки учащимся нужно уточнить лексическую семантику. Чёрненькая собачка, свернувшись, лежит, не лает, не кусает, а в дом не пускает (замок). В этой загадке ключевыми являются слова собачка, лаять, кусать, пускать, без определения значений которых невозможно отгадать загадку.

2) Увеличить словарный запас. Содержание загадок охватывает различные темы: времена года, жилище, мир природы (погодные явления, животные, птицы, лес и т. д.), еда, предметы быта, профессии и др. В загадках сконцентрированы слова многих лексико-тематических групп.

3) Рассмотреть словообразовательный аспект. В загадке обычно присутствуют слова с уменьшительно-ласкательными суффиксами, чередованиями, что создает потенциал для словообразовательной работы.

4) Разобрать грамматические явления, например, род, число, падеж существительных и прилагательных, вид и время глагола, функции синтаксических конструкций и т. д.

5) Познакомиться с культурой и менталитетом носителей языка: загадка описывает какие-либо предметы и явления, по-разному представленные в русской и родной картинах мира.

6) Развивать речевые навыки: учащиеся не просто дают ответ на загадку, но и аргументируют его. Кроме того, отгадка может стать стимулом для говорения, толчком в развитии темы.

Преподаватели могут использовать загадки в следующих целях.

1) Организовать ход урока. Например, в начале занятия преподаватель дает студентам загадки, позволяющие учащимся догадаться о теме урока. Снег на полях, лёд на реках, вьюга гуляет... Когда это бывает? [Старикова 2017: 64]. Ключевые слова снег, лёд, вьюга подсказывают, что тема урока - «Зима». Этот праздник объеденье! Напечём блины с утра. К ним - сметана и варенье, и, конечно же, икра [Нестерова 2015: 67]. Эта загадка о празднике Масленицы. Таким образом, презентация темы урока осуществляется более интересным способом. 
2) Разнообразить формы работы. Загадки позволяют сделать урок насыщеннее, внести элемент соревновательности, организовать работу в командах и т. п.

3) Выявить трудности лексико-грамматического и лингвокультурологического характера.

4) Поощрить интерес к русскому языку. Загадки содержат неожиданные, остроумные образы, они часто юмористичны, что способствует интересу учащихся.

\section{ПРИНЦИПЫ ОТБОРА ЗАГАДОК НА УРОКАХ РКИ}

При выборе загадок в качестве дидактического материала, во-первых, важно учитывать их лексико-грамматические характеристики, они должны соответствовать уровню владения языком. Например, разгадать загадку Чего нет в России, есть в Москве, нет в Петербурге, есть в Неве? (буква В) [Чернышов 2009: 166] будет по силам даже начинающим. Приведем еще несколько подобных примеров: «Xu-xu-xu, ха-ха-ха!» - Так хохочет буква... (X); Не получится борщуа, если нет в нём буквыл... (Щ); У тебя есть - у меня нет, у бабы две - у девки нет, у Бориса спереди - у Глеба сзади (Б). [Зуева, Кирдан 2009: 133]. Студентам, владеющим языком на более продвинутом уровне, можно предложить такие загадки: Меня одну не едят, а без меня мало едят. От воды родится, воды боится (соль); Без огня горит, без крыльев летит, без ног бежит, без ран болит (солнце, туча, река, сердие).

Во-вторых, нужно учитывать также лингвокультурологические и лингвострановедческие компетенции учащихся. Студентам, обладающим знаниями о русских культурных реалиях (в том числе и устаревших), можно предложить отгадать эти загадки: 1) Стоит Алёна: платок зелёный, тонкий стан, белый сарафан (берёза); 2) Этот праздник знаешь ты, на него печём блины. Зиму прочь им прогоняем, весну красную встречаем (Масленица). 3) Знают все, на Пасху мы светить ходим куличи. А еще красим его, символ Пасхи ведь... (яйцо). Преподаватель должен дать лингвокультурологический комментарий к таким загадкам, привлечь иллюстративный материал для облегчения процесса отгадывания. Кроме того, такого рода загадки становятся источником знаний о русской традиционной и современной культуре.

Таким образом, самый важный принцип отбора загадки - удобопонятность. Загадки демонстрируют разницу языковых картин мира, тексты загадок должны быть понятны учащимся и в то же время служить источником новых знаний о культуре.

\section{СИСТЕМА УПРАЖНЕНИЙ И ЗАДАНИЙ К ЖАНРУ ЗАГАДКИ НА УРОКАХ РКИ}

Жанр загадки в качестве учебного материала можно использовать в упражнениях на всех уровнях языковой системы.

Тексты загадок короткие, часто рифмованные, поэтому целесообразно применять их на занятиях по фонетике или фрагментарно вводить в другие уроки для отработки произношения звуков. Например, китайским студентам трудно произносить звуки [P], [C], [Ш], учащимся можно предложить такое задание: Прочитайте эти загадки, отгадайте их. Попробуйте читать их быстро.

1) Рак, рыбалка, рыболов, рыба, речка... сколько слов! Вы скажите как пример хоть словечко с буквой... (P).

2) Эта буква нам важна: слову «Родина» нужна. «Речь родная», "русский» тоже без неё прожить не сможет. Буква нужная, поверь! Эта буква... (P).

3) Висит милашка - красная рубашка, брюшко сыто, зёрнами набито (шиповник).

4) Маленький шарик под лавкою шарит (мышь). 
Когда учащиеся прочитают и отгадают загадки, одновременно тренируясь в произношении звуков, они закрепят в памяти значения слов и увеличат словарный запас. Учащимся нужно уточнить семантику слов в процессе отгадывания, сами тексты загадок могут стать источником пополнения словарного запаса. Объектом загадок становятся слова разных лексико-тематических групп: времена года, жилище, пища, природа, предметы быта, профессии и др. Приведем пример использования жанра загадки на занятии для студентов начального уровня по теме «Праздники».

Задание. Посмотрите лексический минимум, найдите незнакомые слова, определите их значение.

Лексический минимум: бусы, водить хоровод, сытый, сметана, чудесный, букет, огонь.

Задание 1. Отгадайте эти загадки и объясните ваши ответы.

1) Если ёлочки в домах, в ярких бусах и огнях, если водим хоровод, что встречаем? (Новый год)

2) Праздник русский и раздольный, вкусный, сытый и довольный, со сметаной, маслиием - что за праздник? (Масленица)

3) Этот день чудесный только раз в году. Для меня все песни и ивветы в саду. Дарят мне подарки, роз большой букет. Что это за праздник, дай скорей ответ! (День рождения)

Задание 2. Скажите, какие слова помогают вам отгадать загадку?

Наличие неизвестных слов в лексическом минимуме облегчит студентам процесс отгадывания загадки, в то же время преподаватель акцентирует внимание учащихся на характерных атрибутах русских праздников.

Загадка также является материалом для изучения грамматики. Например, на уроках, посвященных глаголам движения, можно предложить учащимся такие примеры:

1) Идут, идут, а с места не сойдут (часы).

2) Подушечка с иголками в уголке лежит, никуда пока не бежит (ёж).

3) Течёт, течёт - не вытечет, бежит, бежит - не выбежит (река).

4) Входишь в одну дверь, а выходишь из трёх, думаешь, что вышел, а на самом деле зашёл (рубашка).

Для отгадывания загадок студентам необходимо иметь представление как о прямом, так и о переносном значении глаголов движения.

Другой грамматической темой на материале жанра загадки является тема «Разряды числительных»:

1) Двое смотрят, двое слушают, а один говорит (глаза, уши, язык);

2) Один - седой, другой-молодой, третий - скачет, а четвёртый - плачет (времена года);

3) Какое дерево имеет двенадиать сучьев, на каждом суку по четыре ветки, а на каждой ветке по семи листьев? (год);

4) Утром - на четырёх. Днем - на двух. Вечером - на трёх (человек).

На занятиях по синтаксису тексты загадок можно использовать для изучения однородных членов предложения [Федорова 2013: 515-520]:

1) Однородное сказуемое: Днём молчит, ночью кричит, по лесу летает, прохожих пугает (филин).

2) Однородное определение: Без рук, без ног, а рубашку носит (подушка).

3) Однородное обстоятельство: По нему идут, он и там и тут, он в твоей квартире, в школе, в бане, в тире. И запомнить так легко: он всегда под потол- 


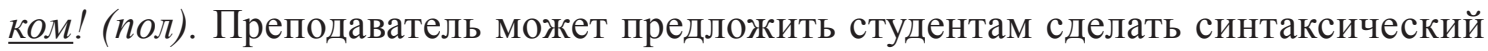
разбор предложения. Также можно использовать эти загадки в качестве учебного материала в теме «Однородные члены предложения».

Жанр загадки считается детским фольклорным жанром, поэтому в текстах есть много слов с уменьшительно-ласкательными суффиксами, что позволяет применять тексты загадок в работе по словообразованию:

1) Говорит дорожка, два вышитых кониа: «Помойся хоть немножко, чернила смой с лица! Иначе ты в полдня испачкаешь меня» (полотенце).

2) Вот серебряный лужок, не видать барашка, не мычит на нём бычок, не иветёт ромашка. Наш лужок зимой хорош, а весною не найдёшь (каток).

3) Танечки и Галочки, Сонечки и Аллочки, Машеньки и Верочки - маленькие... (девочки).

Задание. Какие слова с уменьшительно-ласкательными суффиксами и чередованиями вы нашли? Почему в загадках используют эти слова?

Задание. Напишите, от каких слов образованы эти слова.

Образеи: дорожка - дорога, сучок - сук, Галочка - Галя, Танечка - Таня, Caшенька - Саша.

Немножко..,- лужок..,- бычок..,- , Аллочка..,- Верочка..,- , Сонечка - ..., Машенька - ... .

С помощью загадок учащиеся могут развивать речевые навыки. На занятиях по практике устной речи жанр загадки выступает стимулом для говорения учащихся.

1) Солние лучиком играет, а снежок всё тает, тает! Птичкам стало не до сна, в гости к нам пришла... (весна);

2) Снег идёт, под белой ватой скрылись улииы, дома. Рады снегу все ребята снова к нам пришла... (зима);

3) Сльишно пенье комаров, время ягод и грибов, озеро теплом согрето, всех зовет купаться... (лето);

4) Листья жёлтыле летают, дождик землю поливает. Когда это бывает? (осень).

Студентам нужно не только дать ответ на загадку, но и аргументировать его. Преподаватель задает вопросы студентам.

1) Как вы думаете, к какой теме относятся эти загадки?

2) Какие слова помогают отгадать загадку?

3) Какие слова новые для вас?

4) В вашей культуре есть похожие загадки? Что общего они имеют? Чем отличаются?

Затем преподаватель может дать студентам несколько слов по определенной теме, например, по теме «Погода»: снег, дождь, солние и др. Задача студентов подобрать загадки к этим словам на родном языке, перевести их на русский и позже предложить для отгадывания в группе.

Таким образом, загадки обладают значительным лингвометодическим потенциалом в преподавании и изучении РКИ.

\section{Л ИТ Е РАТ У РА}

Адоньева С.Б. Прагматика фольклора. СПб.: Изд-во С.-Петерб. ун-та, 2004. 312 с.

Аникин В.П. Русские народные пословицы, поговорки, загадки и детский фольклор. М.: Учпедгиз, 1957. 240 с.

Аникин В.П. Русское устное народное творчество: Учебник. М.: Высш. шк., 2001. 726 с. 
Белозубова Н.И., Титова К.А. Изучение детского фольклора на практических занятиях по русскому языку как иностранному // Образование и наука в России и за рубежом. М.: Флинта, 2010. С. 184-189.

Зуева Т.В., Кирдан Б.П. Русский фольклор: Хрестоматия для студентов и преподавателей-филологов. 2-е изд. М.: Флинта: Наука, 2001. 480 с.

Нестерова Н.Г., Шилина В.В., Фащанова С.В. и др. Русский клуб. Томск: Издательский дом ТГУ, 2015. 118 с.

Садовников Д.Н. Загадки русского народа. М.: Изд-во Моск. ун-та, 1960. 333 с.

Старикова Г.Н. Поговорим о русской живописи. Русское искусство на уроках РКИ: учеб. пособие. Томск: Издательский Дом ТГУ, 2017. 128 с.

Федорова Н.И. Однородные члены предложения в системе русских народных загадок как способ репрезентации категории градуирования (на примере загадок, посвященных описанию небесной сферы) // Язык, сознание, коммуникация. М.: Изд-во Моск. ун-та, 2013. C. $515-520$.

Черныпиов С.И. Поехали! Русский язык для взрослых. 7-е изд. СПб.: Златоуст, 2009. 280 с.

\section{REFERENCES}

Adonieva S.B. (2004) Pragmatics of Folklore. St.-Petersburg State University Press. 312 p.

Anikin V.P. (1957) Russian Folk Proverbs, Sayings, Riddles and Children's Folklore. Moscow. Uchpedgiz Publ. 240 p.

Anikin V.P. (2001) Russian Oral Folk Art. Moscow. Vysshaya Shkola Publ. 726 p.

Belozubova N.I., Titova K.A. Studying Children's Folklore in Practical Classes of Russian as a Foreign Language. In: Education and Science in Russia and Abroad. Moscow. Flinta Publ. 2010, pp. 184-189.

Zueva T.V., Cirdan B.P. (2001) Russian Folklore. Reader for Students and Teachers-philologists. $2^{\text {nd }}$ ed. Moscow. Flint: Nauka Publ. 480 p.

Nesterova N.G., Shilina V.V., Faschanova S.V. et al. (2015) Russian Club. Tomsk. Tomsk State University Press. 118 p.

Starikova G.N. (2017) Let's Talk on Russian Painting: Russian Art at the Lessons of RCT: textbook. Tomsk. Tomsk State University Press. 128 p.

Sadovnikov D.N. (1960) Riddles of the Russian People. Moscow State University Press. 333 p.

Fedorova N.I. Homogeneous Members of the Sentence in the System of Russian Folk Riddles as a Way of Representation of the Grading Category (based on examples of riddles devoted to the description of the celestial sphere). In: Language, Consciousness, Communication. Moscow. Moscow State University Press. 2013, pp. 515-520.

Chernyshov S.I. (2009) Let's Go! The Russian Language for Adults. $7^{\text {th }}$ ed. St.-Petersburg. Zlatoust Publ. 280 p.

Сведения об авторе:

Му Юйси,

магистр

филологический факультет

Томский государственный университет
Mu Yuxi,

Magister

Faculty of Philology

Tomsk State University

mu.yuisi@yandex.ru 